\title{
Response of Melon Cultivars to Natural Infection by Diseases in South Western Nigeria
}

\author{
I. A. Kehinde \\ Department of Biological Sciences, University of Agriculture \\ P.M.B. 2240, Alabata road, Abeokuta, Ogun State \\ Tel: 234-803-714-9064Ｅ-mail: iakipm2004@gmail.com
}

Received: May 12, 2011 Accepted: June 9, 2011 doi:10.5539/ijb.v3n4p47

\begin{abstract}
Melon is an important crop in South western, Nigeria. The study evaluated incidence and severity of Anthracnose, mildews, wilt, leaf spot and blight disease of melon cultivars: Serewe, Bara A, Bara B in cultivated plots in South Western Nigeria. Experiment was set in a randomized complete block design with five replicates in the Teaching and Research field of the University of Ibadan, Nigeria. Disease incidence and severity was varied among the melon cultivars. Predominant foliar diseases were Anthracnose and leaf blight with maximum disease incidence index of $82.0-100 \%$ across the cultivars. Disease incidence and severity indices for all diseases were high during the early season (27.0-100\%) and low during the dry season (19.0-65.0\%) except for the downy mildew disease. Fusarium wilt disease incidence was significantly lower than all other diseases encountered. Cultivars were not consistent in their reaction to the diseases and these also varied with the years. The study has given information on the predominant diseases for which control management technology should be developed.
\end{abstract}

Keywords: Egusi melon, Disease incidence, Disease severity, AUDPC

\section{Introduction}

'Egusi' melon is a vegetable crop commonly cultivated in West Africa (Van der Vossen et al., 2004). It is often cultivated yearly as cash crop with other arable crops in the rainy and dry seasons (Adewusi et al., 2000). Egusi melon plays vital role in the farming system and wellbeing of West African rural dwellers as a good source of energy, weed suppressant and for soil fertilization (Achigan Dako et al., 2008, Asoegwu, 1987). It is also used as mulch, leaving high residual nitrogen in the soil after harvest (Mba, 1983), thus helping growers to maintain and restore soil fertility of gardens and fields or land rehabilitation (Adewusi et al., 2000). It prevents rain splashes, which dislodge soil granules and clods, hence, the problem of sheet erosion and subsequently rill erosion are prevented (Okafor and Okolo, 1974; Dupriez and Deleener, 1989). Melon is usually planted before the food crops in traditional mixed cropping system. It is sown with starch staples such as yam (Dioscorea rotundata Poir), maize (Zea mays L.), sorghum (Sorghum bicolor (L.) Moench) and cassava (Manihot esculenta Crantz), in the rainy and dry seasons (Adewusi et al., 2000). This underscores the central place and relevance of this crop in the farming systems and livelihood of rural low-income and subsistent farmers in most parts of West- Africa. As with most minor crops in the mixed cropping system of farmers in Nigeria, the incidence and severity of diseases are rarely documented. However, these diseases contribute largely to reduce yield of most crops as well as get transmitted to other crops. Similarly, latent infection can become foci of inocula build up for subsequent seasons. Pathogens of egusi melon includes Erysiphe cucurbitarum, Peronospora cucurbitarum, Alternaria cucumerina, Cercospora citrullina, Colletotrichum lagenarium, Didymella bryoniae and Fusarium solani (Kehinde, 2008). However, in field conditions of South western Nigeria, the incidence of these disease have not been documented. Therefore, the study evaluated the incidence and severity of diseases encountered in farm plots in South western, Nigeria.

\section{Materials and methods}

Field experiments were conducted in the Teaching and Research Farm of the University of Ibadan, Ibadan during the early season (April to July) and late seasons (August to November) 2003 and 2005. The experiment was in a randomized complete design (RCBD) with five replications. Each block was $4 \times 10 \mathrm{~m}^{2}$ with 3 rows seperated by $2 \mathrm{~m}$ alley. Three cultivars of melon namely Bara A, Bara B and Serewe commonly grown by farmers were used. 
One week after emergence, seedlings were thinned to two plants per stand leaving 20 plants per row. The disease incidence (number of tagged plants with a particular symptom divided by the number of all tagged plants on the plot) was recorded at weekly intervals throughout the life cycle of the plant. Disease severity was rated as the proportion of total damaged tissue relative to total surface area of the selected plant part converted to a scale of 1-5 for leaf and stem, and 1-4 for fruit (Table 1). For Leaf, 10 leaves from 2 vines on each of the 5 selected plants were assessed. For stem, 2 vines on each of the 5 selected plants were assessed. Five randomly selected fruits across the 5 selected plants were assessed.

Area under disease progress curve (AUDPC) was calculated from disease severity ratings using a modified Shaner and Finney (1977) formula:

$$
A U D P C=\sum_{i=1}^{n}\left((1 / 2)\left(y_{i+1}+y_{i}\right)\left(t_{i+1}-t_{i}\right)\right)
$$

Where $\quad y_{i}=$ the disease ratings at the ith observation

$\mathrm{t}_{\mathrm{i}}=$ time (days) at the ith observation

$\mathrm{n}=$ total number of observations

Diseased specimens were taken to the laboratory for isolation and identification of associated fungal organisms. Data on incidence and severity were subjected to analysis of variance (ANOVA), means separation was carried out using the Least Significant Difference and Duncan's Multiple Range Test, where applicable.

\section{Results}

\subsection{Incidence of diseases}

The incidence of foliar diseases in melon cultivars across the two seasons of 2003 and 2005 is shown in Table 2. All cultivars were infected by leaf blight and anthracnose disease in the early season of 2003. However, the incidence of these diseases was lower (range 35.0-65.0\%) in the late season. Anthracnose and leaf blight incidence were significantly $(\mathrm{P} \leq 0.05)$ different across the cultivars when compared with the other leaf diseases in 2003. In 2005, the incidence of leaf blight disease in the early season was between $92.0 \%$ (on cultivar serewe) and $100 \%$ on variety Bara A and Bara B, while the range of maximum incidence of anthracnose disease in early season of 2005 was $82.0-100 \%$ across the cultivars. Maximum incidence of anthracnose and leaf blight diseases in late season of 2005 ranged between $48.0 \%$ and $62.0 \%$.

In both seasons, maximum incidence of downy mildew, powdery mildew, Cercospora leaf spot and Alternaria leaf spot diseases exceeded 22.0\% (in 2003) and 19\% (in 2005). Downy mildew had the highest mean disease incidence in the late season of 2003. However, range of maximum incidence of these diseases was higher in the early season $(27.0-77.0 \%)$ than late seasons $(20 \%-65 \%)$ across both years and the diseases did not differ significantly amongst themselves in their occurrence on the cultivars in both seasons.

Table 3 shows the maximum incidence of stem diseases across the two seasons. In the early season of 2003, the average maximum incidence ranged between $80-100 \%$ for Anthracnose and stem blight. The incidence of Vine wilt was low (2.5-10.0\%) but comparable to other diseases. Anthracnose and stem blight had high incidence of disease $(70-100 \%)$ in the early season of 2003. Anthracnose differed significantly across the cultivars in the early season of 2005. The average maximum incidence was low for all the diseases (12.7-60.7\%) in the late season of 2005. The lowest score were observed on Bara B (53\%), Bara A (9.0\%), and Serewe (38\%).

The maximum incidence for fruit diseases of melon across the two seasons is shown in Table 4 . The incidence of fruit disease was varied among egusi cultivars in the two seasons of 2003 and 2005. Incidence of fruit anthracnose disease was significantly $(\mathrm{P} \leq 0.05)$ lower than fruit rot disease incidence but comparable $(\mathrm{P} \leq 0.05)$ to fruit blight disease incidence on all cultivars in both seasons of 2003. Disease incidence was low for fruit rot, anthracnose and fruit blight in the late season of 2005 (range: 23.7\%-32.7\%).

\subsection{Severity of diseases}

Table 5 shows the severity of foliar diseases of egusi melon across the three cultivars. With a mean AUDPC-DL value of 289.2, the leaf blight disease was the most severe on melon cultivars in early 2003 . This trend was also consistent in late 2003 and both seasons of 2005. Similarly, downy and powdery mildew diseases also had high AUDPC-DL values. However, severity of the foliar diseases was higher in the early seasons (range 157.3-292 in 2003 and 153.6-274.8 in 2005) than late seasons (range 120.1-281.0 in 2003 and 141.1-257.3 in 2005).

The severity of stem diseases of egusi melon on the three cultivars across the seasons is shown in Table 6. Stem blight disease was most severe (AUDPC values of 218.9 and 149.7) in both early and late seasons of 2003 
respectively. This same pattern was observed in the early season of 2005 but with low severity index (180.5) in the late season. Anthracnose disease had the highest severity index in the late season of 2005.

Table 7 shows the severity of fruit diseases of egusi melon across the seasons on the three melon variety. In the early and late seasons of 2003, fruit rot was the most severe with mean AUDPC values of 182.0 and 171.9. This same pattern was also observed in the two seasons of 2005. The lowest severity index was observed for anthracnose disease in both seasons of 2003 and 2005. Fruit disease severity was higher in the early seasons than in the late seasons.

\section{Discussion}

The present study showed that Anthracnose and leaf blight diseases in South Western Nigeria are more prevalent during the early season on egusi melon crop than in the late season. This implies that the crop is more susceptible to the diseases during the rainy season and thus may be due to the high relative humidity and also because the spores require periods of rainfall for dispersal, infection and invariably, disease development (Averre, 1991). Sherf and Macnab (1999), had also observed that the disease thrives well where wet growing seasons prevail. Topit and Sovali, 2010 also indicated that the diversity, incidence and spread of fungal diseases increases during more humid growth periods. Other diseases such as powdery mildew, Cercospora leaf spot and Alternaria also had high incidences but with low severity during the early season. This probably is due to the ability of the fungus to flourish in periods with high humidity.

The differences in the level of disease incidence in the two years may have been because of the different environmental factors that existed. It is likely that as reported on winter rye (Topit and sovali, 2010), favourable environmental factors play major roles in the determination of incidence and severity of disease of crop plants like egusi melon.

Anthracnose and leaf blight diseases were noted to be more prevalent and leaf blight more severe across the three cultivars than the other foliar diseases. The ability for the two pathogens (Colletotrichum and Didymella) to survive on fields in plant debris from previously infected plants or introduced from contaminated seeds may be the reason for the occurence. The ability for the fungal pathogens to penetrate all parts of the plants may also have contributed to the high incidence levels. These fungal pathogens have been reported to be able to survive in soil for long periods of up to two years in the absence of a suitable host (McAvoy, 2000; Ferrin, 2008; Averre, 1991). High leaf blight severity may be as a result of the influence of Didymella on the cultivars assessed and ability of the spores to stay long in soils. Park et al. (1996) observed that the diseases occurred severely in old fields of melon with successive cropping when compared with new fields.

All diseases were observed to be low during the dry season except for downy mildew disease in which the incidence occurred highest of all the diseases in the late season. In the early season the disease was still relatively high when compared with other diseases such as powdery mildew, cercospora leaf spot and Alternaria leaf spot. This could be due to the ability of the fungus to be easily carried by rain splash, wind current and farm implements and the spore development which is favoured by cool and moderately warm temperatures, adaptability to hot temperature.

The low incidence of vine wilt disease observed in this study is contrary to the findings of Pivonia et al., 1997 who reported that Fusarium spp. especially solani and Pythium spp. which were very common in fields in the Northern and Central Arava of Israel had high disease incidence which ranged from $71-100 \%$. The different environmental factors and different cultivars may be the reason for the result obtained.

Severity of all foliar diseases were relatively high in the early season except for the cercospora leaf spot disease in this study.

The incidence and severity of diseases of melon in Nigeria has rarely been documented. Reports of this findings has therefore provided a basis for further studies on egusi melon. Mossler and Nesheim (2005) noted that yield loss is proportional to severity of the disease and the length of time plants have been infected. The incidence and severity indexes of diseases reported in this study have been shown to be high enough and therefore capable of causing significant economic yield losses where the crop is grown. Anthracnose and blight disease should be investigated more in details in future for disease control strategies.

\section{References}

Achigan Dako, G. E., Vodouhe, S. R. and Sangare, A. (2008). Caracterisation morphologique des cultivars locaux des Lagenaria siceraria (Curcubitaceae) collectes au Benin et au Togo. Belgium J. Bot, 141: 21-38. 
Adewusi, H.G., Ladipo, D.O., Sarumi, M.B. and Vodouhe, R. (2000). Egusi production, utilization and diversity in Nigeria. In: Agronomy in Nigeria. Polygraphics venture Ltd, Ibadan. pp 94-100.

Asoegwu. S. N. (1987). Tillage effects of egusi melon (Coloncynthis citrullus L.) production in Nigeria. Proc. of the 12th Annual conf. Hort. Soc, pp84-91.

Averre, W. C. (1991). Anthracnose of cucurbits. [Online] Available: http/www.ces.ncsu.edu/depts/pp/notes/vegetable/udir011/vdin 011.htm (April 20, 2011)

Dupreiz, H. and Deleener, P. (1989). African gardens and orchards (Growing vegetables and fruits). Macmillan Publishers Ltd. London and Basingstoke. pp275-285.

Ferrin D. M. (2008). Foliar diseases of water melon. Louisiana Plant Pathology disease identification and management series. [Online] Available: http/ www.lsuagcenter.lsu.edu (February 10, 2011)

Kehinde, I. A. (2008). Identification and control of field and storage fungal pathogens of egusi melon. Citrullus lanatus (Thunb). Mansf in South Western, Nigeria. Ph.D. thesis pp 211.

Mba, C.C. (1983). Egusi plant (Colocynthis citrullus and soil properties. Paper presented at the 6th Annual Conf. of Hort. Soil of Nig. Vegetables for the humid tropics. A newspaper and annual communication among Res. Workers No. 2: 37-39.

McAvoy, G. (2000). Southwest Florida Veg. pest and disease hotline. [Online] Available: http://www/swfloridapestandDiseaseshotline-3-14-00.htm (February 25, 2011)

Mossler, M. A. and Nesheim, O. N. (2005). Florida crop/pest management profile: Squash. Electronic Data Information Source of UF/IFAS Extension (EDIS). CIR. 1265. [Online] Available: http/edis.ifas.ufl.edu/. (April 20, 2010)

Okafor, J.C. and Okolo, H.C. (1974). Potentialities of some indigenous fruit trees of Nigeria. Paper presented at the symposium on variation and breeding systems of Triplochiton scleroxylon. Dept. Forest Research Ibadan, Nigeria.

Park, S.D., Kwon-T.Y., Lim, Y.S., Jung, K. and Choic, B.S. (1996). Disease survey in melon, water-melon and cucumber with different successive cropping under viny/house conditions. Korean Journal of Plant pathology, 12. 4: 428-431.

Pivonia, S., Cohen, R., Kafkafi, U., Ben Ze'ev, I. S. and Katan, J. (1997). Sudden wilt of melons in Southern Israel. Fungal agents and relationship with plant development. Plant Disease, 81: 1264-1268. http://dx.doi.org/10.1094/PDIS.1997.81.11.1264

Shaner, G. and Finney, E. R. E. (1977). The effect of nitrogen fertilization in the expression of slow-mildewing resistance in Knox wheat. Phytopathology, 67: 1051-1056. http://dx.doi.org/10.1094/Phyto-67-1051

Sherf, F. A. and Macnab, A. A. (1999). Vegetable diseases and their control. 2nd Ed. John wiley Pub. and Sons. New York p728.

Topit, I. and Sovali, P. (2010). The occurrence and severity of rust diseases of winter rye in Estonian climatic conditions. Agronomy Research, 8(3): 735-742.

Van der Vossen, H. A. M., Denton, O. A. and El Tahir, I.M. (2004). Citrullus lanatus In: G.J.H. Grubben, O.A. Denton (Eds.): Plant resources of Tropical Africa vegetables. Wageningen. The Netherlands. CTA; Leiden, The Netherlands: Buckhuys Publishers. Pp 185-191.

Table 1. Disease severity rating scale for leaf, stem, and fruit of egusi melon

\begin{tabular}{lll}
\hline Scale & Leaf and stem & Fruit \\
\hline 1 & No symptom & No symptom \\
2 & $<10 \%$ damaged portion & $<30 \%$ damaged portion \\
3 & $10-30 \%$ damaged portion & $31-50 \%$ damaged portion \\
4 & $31-50 \%$ damaged portion & $>50 \%$ damaged portion \\
5 & $>50 \%$ damaged portion & \\
\hline
\end{tabular}

Source: Kehinde, 2008 
Table 2. Maximum incidence of foliar diseases (Mf - Ds) of egusi melon in Southwestern, Nigeria

\begin{tabular}{|c|c|c|c|c|c|c|c|c|}
\hline \multirow[t]{2}{*}{ Season } & \multirow[t]{2}{*}{ Variety } & \multicolumn{7}{|c|}{ *Mf - Ds $\quad(\%)$} \\
\hline & & $\begin{array}{l}\text { Downy } \\
\text { mildew }\end{array}$ & $\begin{array}{l}\text { Powdery } \\
\text { mildew }\end{array}$ & $\begin{array}{l}\text { Cercospora } \\
\text { leaf spot }\end{array}$ & $\begin{array}{l}\text { Alternaria } \\
\text { leaf spot }\end{array}$ & Anthracnose & $\begin{array}{l}\text { Leaf } \\
\text { blight }\end{array}$ & $\begin{array}{l}\text { LSD } \\
(\mathrm{P} \leq 0.05)\end{array}$ \\
\hline \multirow{3}{*}{$\begin{array}{l}\text { Early } \\
2003\end{array}$} & Bara -A & 42.5 & 55.0 & 32.5 & 65.0 & 100.0 & 100.0 & 21.5 \\
\hline & Bara - B & 42.5 & 52.5 & 30.0 & 75.0 & 100.0 & 100.0 & 22.3 \\
\hline & Serewe & 27.0 & 47.5 & 27.5 & 60.0 & 100.0 & 100.0 & 24.9 \\
\hline Mean & & 37.5 & 51.7 & 30.0 & 66.7 & 100.0 & 100.0 & \\
\hline $\begin{array}{l}\text { LSD } \\
(\mathrm{P}<0.05)\end{array}$ & & 12.3 & 5.3 & 3.4 & 10.5 & 0.0 & 0.0 & \\
\hline \multirow[t]{3}{*}{ Late 2003} & Bara -A & 62.5 & 32.5 & 25.0 & 50.0 & 65.0 & 55.0 & 12.2 \\
\hline & Bara - B & 65.0 & 30.0 & 32.5 & 45.0 & 57.5 & 42.5 & 10.3 \\
\hline & Serewe & 52.5 & 22.5 & 27.5 & 37.0 & 50.0 & 35.0 & 9.0 \\
\hline Mean & & 60.0 & 28.3 & 28.3 & 44.2 & 57.5 & 44.2 & \\
\hline $\begin{array}{l}\text { LSD } \\
(\mathrm{P}<0.05)\end{array}$ & & 9.1 & 7.2 & 5.3 & 9.0 & 10.3 & $13 . .9$ & \\
\hline \multirow{3}{*}{$\begin{array}{l}\text { Early } \\
2005\end{array}$} & Bara -A & 33.0 & 30.0 & 47.0 & 77.0 & 90.0 & 100.0 & 22.6 \\
\hline & Bara - B & 36.0 & 45.0 & 42.0 & 73.0 & 100.0 & 100.0 & 22.0 \\
\hline & Serewe & 30.0 & 30.0 & 38.0 & 65.0 & 82.0 & 92.0 & 20.5 \\
\hline Mean & & 33.0 & 35.0 & 42.3 & 71.7 & 90.7 & 97.3 & \\
\hline $\begin{array}{l}\text { LSD } \\
(\mathrm{P}<0.05)\end{array}$ & & 4.1 & 11.9 & 6.2 & 8.4 & 12.4 & 6.4 & \\
\hline \multirow[t]{3}{*}{ Late 2005} & Bara -A & 55.0 & 25.0 & 28.0 & 54.0 & 50.0 & 57.0 & 10.8 \\
\hline & Bara - B & 45.0 & 20.0 & 25.0 & 48.0 & 54.0 & 62.0 & 12.4 \\
\hline & Serewe & 42.0 & 19.0 & 29.0 & 59.0 & 48.0 & 55.0 & 11.6 \\
\hline Mean & & 49.3 & 21.3 & 27.3 & 53.6 & 50.7 & 58.0 & \\
\hline $\begin{array}{l}\text { LSD } \\
(\mathrm{P}<0.05)\end{array}$ & & 9.4 & 4.4 & 2.9 & 7.6 & 4.2 & 5.0 & \\
\hline
\end{tabular}

*Mf - Ds: Data obtained at $12^{\text {th }}$ week after planting 
Table 3. Maximum incidence of stem diseases (Ms - Ds) of egusi melon in Southwestern, Nigeria

\begin{tabular}{|c|c|c|c|c|c|}
\hline \multirow[t]{2}{*}{ Season } & \multirow[t]{2}{*}{ Variety } & \multicolumn{4}{|c|}{ *Mf-DS $\quad(\%)$} \\
\hline & & Anthracnose & Vine wilt & $\begin{array}{l}\text { Stem } \\
\text { blight }\end{array}$ & $\begin{array}{l}\text { LSD } \\
(\mathrm{P} \leq 0.05)\end{array}$ \\
\hline \multirow[t]{3}{*}{ Early 2003} & Bara -A & 100.0 & 10.0 & 92.5 & 68.7 \\
\hline & Bara - B & 100.0 & 2.5 & 95.0 & 75.6 \\
\hline & Serewe & 92.5 & 7.5 & 80.0 & 63.2 \\
\hline Mean & & 97.5 & 6.7 & 89.2 & \\
\hline $\begin{array}{l}\text { LSD } \\
(\mathrm{P}<0.05)\end{array}$ & & 6.0 & 5.3 & 11.1 & \\
\hline \multirow[t]{3}{*}{ Late 2003} & Bara -A & 87.5 & 7.5 & 82.5 & 61.7 \\
\hline & Bara - B & 67.5 & 0.0 & 77.5 & 58.0 \\
\hline & Serewe & 70.0 & 7.5 & 77.5 & 52.9 \\
\hline Mean & & 75.0 & 5.0 & 79.2 & \\
\hline $\begin{array}{l}\text { LSD } \\
(P<0.05)\end{array}$ & & 15.0 & 6.0 & 4.0 & \\
\hline \multirow[t]{3}{*}{ Early 2005} & Bara -A & 100.0 & 12.0 & 98.0 & 69.2 \\
\hline & Bara - B & 100.0 & 10.0 & 98.0 & 70.7 \\
\hline & Serewe & 100.0 & 14.0 & 70.0 & 60.1 \\
\hline Mean & & 100.0 & 12.0 & 88.7 & \\
\hline $\begin{array}{l}\text { LSD } \\
(\mathrm{P}<0.05)\end{array}$ & & 0.0 & 2.8 & 22.3 & \\
\hline \multirow[t]{3}{*}{ Late 2005} & Bara -A & 72.0 & 9.0 & 52.0 & 44.3 \\
\hline & Bara - B & 53.0 & 16.0 & 42.0 & 26.2 \\
\hline & Serewe & 57.0 & 13.0 & 38.0 & 30.4 \\
\hline Mean & & 60.7 & 12.7 & 44.0 & \\
\hline $\begin{array}{l}\text { LSD } \\
(P<0.05)\end{array}$ & & 13.8 & 4.8 & 10.2 & \\
\hline
\end{tabular}

*Ms - Ds: Data obtained at $12^{\text {th }}$ week after planting 
Table 4. Maximum incidence of fruit diseases (Mfd - Ds) of egusi melon in Southwestern, Nigeria

\begin{tabular}{|c|c|c|c|c|c|}
\hline \multirow[t]{2}{*}{ Season } & \multirow[t]{2}{*}{ Variety } & \multicolumn{3}{|c|}{$* \mathrm{Mfd}-\mathrm{DS} \quad(\%)$} & \multirow[b]{2}{*}{$\begin{array}{l}\text { LSD } \\
(\mathrm{P} \leq 0.05)\end{array}$} \\
\hline & & Fruit rot & Anthracnose & $\begin{array}{l}\text { Fruit } \\
\text { blight }\end{array}$ & \\
\hline \multirow{3}{*}{ Early 2003} & Bara -A & 55.0 & 22.5 & 35.0 & 22.6 \\
\hline & Bara - B & 47.5 & 22.5 & 32.5 & 17.3 \\
\hline & Serewe & 37.5 & 15.0 & 27.5 & 15.5 \\
\hline Mean & & 46.7 & 20.0 & 31.7 & \\
\hline $\begin{array}{l}\text { LSD } \\
(\mathrm{P}<0.05)\end{array}$ & & 12.1 & 6.0 & 5.2 & \\
\hline \multirow[t]{3}{*}{ Late 2003} & Bara -A & 52.5 & 25.0 & 35.0 & 19.2 \\
\hline & Bara - B & 35.0 & 30.0 & 35.0 & 8.7 \\
\hline & Serewe & 35.0 & 22.5 & 30.0 & 8.7 \\
\hline Mean & & 40.8 & 25.8 & 33.3 & \\
\hline $\begin{array}{l}\text { LSD } \\
(\mathrm{P}<0.05)\end{array}$ & & 14.0 & 5.3 & 4.0 & \\
\hline \multirow[t]{3}{*}{ Early 2005} & Bara -A & 66.0 & 66.0 & 52.0 & 11.1 \\
\hline & Bara - B & 72.0 & 52.0 & 49.0 & 17.2 \\
\hline & Serewe & 61.0 & 38.0 & 42.0 & 17.0 \\
\hline Mean & & 66.3 & 52.0 & 47.7 & \\
\hline $\begin{array}{l}\text { LSD } \\
(\mathrm{P}<0.05)\end{array}$ & & 7.6 & 19.3 & 7.1 & \\
\hline \multirow[t]{3}{*}{ Late 2005} & Bara -A & 34.0 & 35.0 & 24.0 & 8.3 \\
\hline & Bara - B & 38.0 & 24.0 & 25.0 & 10.8 \\
\hline & Serewe & 26.0 & 32.0 & 22.0 & 6.9 \\
\hline Mean & & 32.7 & 30.2 & 23.7 & \\
\hline $\begin{array}{l}\text { LSD } \\
(\mathrm{P}<0.05)\end{array}$ & & 8.4 & 7.8 & 2.1 & \\
\hline
\end{tabular}

*Mfd - Ds: Data obtained at $12^{\text {th }}$ week after planting

Table 5. Area Under Disease Progress Curve for diseased leaf (AUDPC-DL) of melon cultivars in early and late seasons of 2003 and 2005 in South Western Nigeria

\begin{tabular}{|c|c|c|c|c|c|c|c|c|}
\hline \multirow[t]{2}{*}{ Season/year } & \multirow[t]{2}{*}{ Variety } & \multirow[b]{2}{*}{$\begin{array}{l}\text { Downy } \\
\text { mildew }\end{array}$} & \multirow[b]{2}{*}{$\begin{array}{l}\text { Powdery } \\
\text { mildew }\end{array}$} & \multirow[b]{2}{*}{$\begin{array}{l}\text { Cercospora } \\
\text { leaf spot }\end{array}$} & \multirow[b]{2}{*}{$\begin{array}{l}\text { Alternaria } \\
\text { leaf spot }\end{array}$} & \multicolumn{3}{|c|}{ AUDPC- DL } \\
\hline & & & & & & Anthracnose & $\begin{array}{l}\text { Leaf } \\
\text { blight }\end{array}$ & $\begin{array}{l}\text { LSD } \\
(\mathrm{P}<0.05)\end{array}$ \\
\hline \multirow[t]{3}{*}{ Early 2003} & Bara A & 311.4 & 325.5 & 171.8 & 229.9 & 269.0 & 292.5 & 43.1 \\
\hline & Bara B & 281.8 & 313.0 & 164.9 & 239.0 & 250.8 & 291.4 & 39.4 \\
\hline & Serewe & 258.9 & 298.5 & 157.3 & 215.4 & 250.9 & 283.8 & 38.5 \\
\hline Mean & & 284.0 & 311.7 & 164.7 & 223.1 & 257.2 & 289.2 & \\
\hline $\begin{array}{l}\text { LSD } \\
(\mathrm{P}<0.05)\end{array}$ & & 36.2 & 18.6 & 10.0 & 16.4 & 14.4 & 6.5 & \\
\hline \multirow[t]{3}{*}{ Late 2003} & Bara A & 252.8 & 140.5 & 128.4 & 167.4 & 174.8 & 281.8 & 46.7 \\
\hline & Bara B & 239.0 & 127.3 & 146.5 & 162.8 & 167.6 & 255.5 & 39.0 \\
\hline & Serewe & 216.9 & 120.1 & 124.9 & 143.9 & 154.0 & 240.6 & 37.7 \\
\hline Mean & & 236.2 & 129.3 & 133.3 & 158.0 & 165.5 & 259.5 & \\
\hline $\begin{array}{l}\text { LSD } \\
(P<0.05)\end{array}$ & & 29.9 & 14.2 & 16.0 & 17.1 & 14.5 & 28.7 & \\
\hline \multirow[t]{3}{*}{ Early 2005} & Bara A & 235.1 & 227.4 & 181.6 & 218.0 & 269.0 & 274.8 & 25.9 \\
\hline & Bara B & 234.3 & 214.1 & 185.8 & 222.4 & 250.8 & 268.0 & 21.6 \\
\hline & Serewe & 215.3 & 264.5 & 153.6 & 214.4 & 250.9 & 261.8 & 31.6 \\
\hline Mean & & 228.2 & 235.3 & 173.7 & 218.3 & 257.2 & 268.2 & \\
\hline $\begin{array}{l}\text { LSD } \\
(\mathrm{P}<0.05)\end{array}$ & & 15.4 & 36.0 & 24.1 & 5.5 & 14.4 & 9.0 & \\
\hline \multirow[t]{3}{*}{ Late 2005} & Bara A & 252.1 & 149.8 & 150.1 & 181.3 & 204.3 & 257.3 & 35.8 \\
\hline & Bara B & 230.1 & 131.6 & 145.1 & 181.5 & 189.3 & 232.9 & 31.5 \\
\hline & Serewe & 220.5 & 141.1 & 143.4 & 177.9 & 185.8 & 232.6 & 28.5 \\
\hline Mean & & 234.2 & 140.8 & 146.2 & 180.2 & 193.1 & 240.9 & \\
\hline $\begin{array}{l}\text { LSD } \\
(\mathrm{P}<0.05)\end{array}$ & & 22.3 & 12.5 & 4.8 & 2.8 & 13.5 & 19.5 & \\
\hline
\end{tabular}


Table 6. Area Under Disease Progress Curve for diseased stem (AUDPC-DL) of melon cultivars in early and late seasons of 2003 and 2005 in South Western Nigeria

\begin{tabular}{|c|c|c|c|c|c|}
\hline \multirow[t]{2}{*}{ Season/year } & \multirow[t]{2}{*}{ Variety } & \multicolumn{4}{|c|}{ AUDPC- DL } \\
\hline & & Anthracnose & Vine wilt & Stemblight & $\begin{array}{l}\text { LSD } \\
(\mathrm{P}<0.05)\end{array}$ \\
\hline \multirow[t]{3}{*}{ Early 2003} & Bara A & 186.1 & 161.8 & 220.8 & 40.8 \\
\hline & Bara B & 182.8 & 109.3 & 225.8 & 81.1 \\
\hline & Serewe & 175.6 & 133.8 & 210.3 & 52.7 \\
\hline Mean & & 181.5 & 135.0 & 218.9 & \\
\hline LSD $(\mathrm{P}<0.05)$ & & 7.4 & 36.2 & 10.9 & \\
\hline \multirow[t]{3}{*}{ Late 2003} & Bara A & 114.5 & 160.0 & 154.5 & 34.2 \\
\hline & Bara B & 109.1 & 76.0 & 144.9 & 47.4 \\
\hline & Serewe & 103.1 & 121.5 & 149.8 & 32.4 \\
\hline Mean & & 108.9 & 119.2 & 149.7 & \\
\hline LSD $(\mathrm{P}<0.05)$ & & 7.8 & 57.9 & 6.6 & \\
\hline \multirow[t]{3}{*}{ Early 2005} & Bara A & 203.5 & 146.0 & 206.9 & 47.1 \\
\hline & Bara B & 198.9 & 167.0 & 215.4 & 33.9 \\
\hline & Serewe & 184.9 & 238.8 & 217.3 & 37.3 \\
\hline Mean & & 195.8 & 183.9 & 213.2 & \\
\hline LSD $(\mathrm{P}<0.05)$ & & 13.3 & 66.9 & 7.6 & \\
\hline \multirow[t]{3}{*}{ Late 2005} & Bara A & 191.9 & 167.0 & 185.6 & 17.8 \\
\hline & Bara B & 179.6 & 181.0 & 177.4 & 2.5 \\
\hline & Serewe & 177.3 & 174.0 & 178.6 & 3.3 \\
\hline Mean & & 182.9 & 174.0 & 180.5 & \\
\hline $\operatorname{LSD}(\mathrm{P}<0.05)$ & & 10.8 & 9.6 & 6.1 & \\
\hline
\end{tabular}


Table 7. Area Under Disease Progress Curve for diseased fruits (AUDPC-DL) of melon cultivars in early and late seasons of 2003 and 2005 in South Western Nigeria

\begin{tabular}{|c|c|c|c|c|c|}
\hline \multirow[t]{2}{*}{ Season/year } & \multirow[t]{2}{*}{ Variety } & \multicolumn{4}{|c|}{ AUDPC-DL } \\
\hline & & Fruit rot & Anthracnose & $\begin{array}{l}\text { Fruit } \\
\text { blight }\end{array}$ & $\begin{array}{l}\text { LSD } \\
(P<0.05)\end{array}$ \\
\hline \multirow[t]{3}{*}{ Early 2003} & Bara A & 183.3 & 105.9 & 162.3 & 55.1 \\
\hline & Bara B & 176.9 & 96.6 & 164.1 & 59.4 \\
\hline & Serewe & 183.8 & 97.5 & 152.0 & 60.1 \\
\hline Mean & & 182.0 & 100.0 & 159.5 & \\
\hline $\operatorname{LSD}(\mathrm{P}<0.05)$ & & 5.3 & 7.1 & 9.0 & \\
\hline \multirow[t]{3}{*}{ Late 2003} & Bara A & 173.2 & 100.3 & 149.3 & 51.2 \\
\hline & Bara B & 171.3 & 95.9 & 141.5 & 52.3 \\
\hline & Serewe & 171.3 & 92.4 & 133.6 & 54.3 \\
\hline Mean & & 171.9 & 96.2 & 141.5 & \\
\hline $\operatorname{LSD}(\mathrm{P}<0.05)$ & & 1.5 & 5.4 & 10.8 & \\
\hline \multirow[t]{3}{*}{ Early 2005} & Bara A & 185.0 & 118.1 & 173.1 & 49.1 \\
\hline & Bara B & 185.6 & 110.3 & 165.0 & 53.6 \\
\hline & Serewe & 187.5 & 107.4 & 160.4 & 56.1 \\
\hline Mean & & 186.0 & 111.9 & 166.2 & \\
\hline LSD $(P<0.05)$ & & 1.8 & 7.6 & 8.9 & \\
\hline \multirow[t]{3}{*}{ Late 2005} & Bara A & 168.3 & 103.9 & 136.8 & 44.3 \\
\hline & Bara B & 165.5 & 101.0 & 125.3 & 44.8 \\
\hline & Serewe & 163.0 & 101.9 & 133.1 & 42.1 \\
\hline Mean & & 165.6 & 102.3 & 131.7 & \\
\hline LSD $(\mathrm{P}<0.05)$ & & 3.6 & 2.0 & 8.1 & \\
\hline
\end{tabular}

